\title{
The isocrinine crinoid Isselicrinus Rovereto from the Paleogene of the Americas
}

\author{
Stephen K. Donovan ${ }^{1} \cdot$ Sven N. Nielsen ${ }^{2} \cdot J_{\text {. Velez-Juarbe }}^{3} \cdot$ Roger W. Portell $^{4}$
}

Received: 8 May 2019 / Accepted: 30 May 2019/Published online: 15 June 2019

(C) Akademie der Naturwissenschaften Schweiz (SCNAT) 2019

\begin{abstract}
Crinoids are uncommon fossils in the Cenozoic. This scarcity means that even disarticulated elements are of note. Two species of the isocrinine Isselicrinus Rovereto are described from their disarticulated columns. Isselicrinus sp. A is from the upper Eocene Moritzian Stage of Tierra del Fuego. These crinoids have a robust column, varying from pentalobate (proximal?) to rounded pentagonal (distal?) in section and with consistently depressed areola petals. Isselicrinus sp. B is from the Lower Oligocene Juana Diaz Formation of Puerto Rico. This species is typified by slender pluricolumnals, always rounded pentagonal in section, and long noditaxes. Proximal and distal pluricolumnal morphologies are not distinguishable.
\end{abstract}

Keywords Tierra del Fuego $\cdot$ Puerto Rico $\cdot$ Oligocene $\cdot$ Systematics $\cdot$ Taphonomy

\section{Introduction}

"As a result of the distribution of sea and land during the Tertiary, which was similar to that of today, most marine sediments were deposited in shallow water close to present coastlines. Therefore, there are only a few chances to collect from deposits in which crinoids might be well preserved ... the extreme rarity of well-preserved crinoids in such [shallow water] sediments, is therefore no surprise" (Hess 1999, p. 233).

Hess rightly emphasized the poor fossil record of Cenozoic crinoids, highlighting the remains of well-preserved specimens. The only common crinoids in shallow-

Editorial Handling: D. Marty.

Stephen K. Donovan

Steve.Donovan@naturalis.nl

1 Taxonomy and Systematics Group, Naturalis Biodiversity Center, Postbus 9517, 2300 RA Leiden, The Netherlands

2 Instituto de Ciencias de la Tierra, Universidad Austral de Chile, Valdivia, Chile

3 Natural History Museum of Los Angeles County, 900 West Exposition Boulevard, Los Angeles, CA 90007, USA

4 Florida Museum of Natural History, University of Florida, Gainesville, FL 32611, USA water deposits from this interval were the comatulids, whose fossil record remains patchy because of their low preservation potential and the small size of their component parts. The tiny ossicles of comatulids rarely occur in concentrations, so it takes a keen eye to spot them. For example, from the upper Oligocene shelf limestones of Jamaica, the late Hal Dixon collected over a thousand echinoids and echinoid fragments (Dixon and Donovan 1998), and the first asteroid (Blake et al. 2015) and ophiuroid ossicles from the island, yet the entire crinoid diversity is a single (presumed comatulid) brachial ossicle (Dixon et al. 1994). Yet, in contrast and also from Jamaica, the deep water fore-reef limestones of the Manchioneal Formation (lower Pleistocene) have yielded a moderate diversity of stem ossicles from isocrinine and bourgueticrinid crinoids (Donovan 1995), but no complete specimens.

It is, therefore, significant to record fossil crinoids from two new Paleogene localities. Both sites have yielded pluricolumnals of the isocrinine Isselicrinus Rovereto, 1914. These remains are morphologically distinct and are identified as such, while leaving both species in open nomenclature until more, and more complete, specimens become available. To prevent confusion, although left in open nomenclature, the specimens from the two localities are separated by a lettered suffix. 
Terminology of the crinoid endoskeleton follows Moore et al. (1968, 1978), Ubaghs (1978) and Webster (1974). Specimens discussed herein are deposited in the Naturalis Biodiversity Center, Leiden, the Netherlands (specimen numbers prefixed by RGM) and the Florida Museum of Natural History, Gainesville (prefix UF).

\section{Localities and horizons}

Puerto Rico Material from Puerto Rico was collected from Florida Museum of Natural History Locality RP012. This is from the northwestern side of the city of Ponce, in a road cut on the southwestern side of PR-9, about $1.1 \mathrm{~km}$ (0.7 mile) east of junction with PR-123 (GPS 18.0311580, -66.6303, Datum WGS84) (Fig. 1).

This is an exposure of the lower Oligocene Juana Diaz Formation (Larue 1994, fig. 8.5). The thinly-bedded limestones occur in a cliff face nearly $15 \mathrm{~m}$-high (Fig. 2). The unit contains mouldic remains of gastropods and bivalves (e.g., Lucinidae) and fossil traces (small infilled tubes). The calcitic taxa include rare body fossils of the epitonid gastropod Sthenorytis, common echinoid test fragments and radioles (e.g., Cidaridae), asteroid ossicles, ostracode valves and crinoid pluricolumnals.

The specimens were collected in situ during two collecting trips. The first was by J. Velez-Juarbe and E. Maiz (17 March 2011), and the second by J. Velez-Juarbe, R.W. Portell, B.A. Kittle, J. Bryan, A. Klompmaker, A. Hendy, T. Stemann and C. Robins (23 March 2013).

Tierra del Fuego Pluricolumnals from Tierra del Fuego was collected in 2002 by S. Nielsen and K. Bandel from

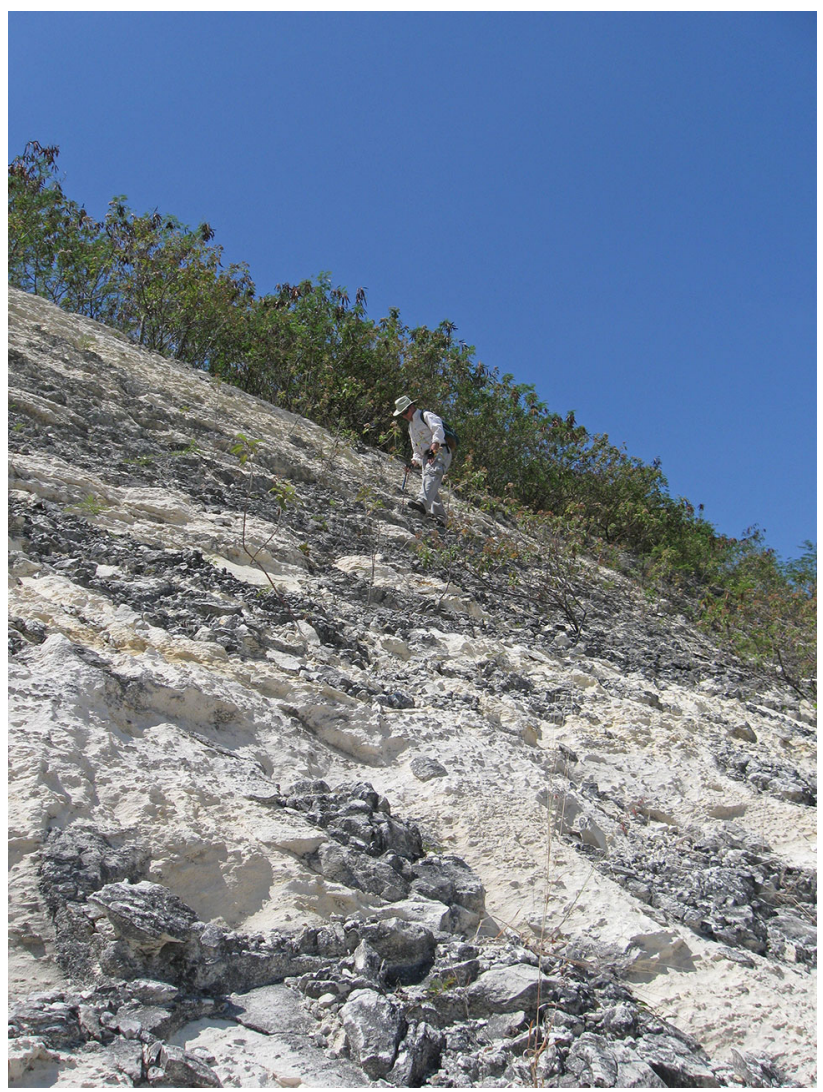

Fig. 2 Florida Museum of Natural History Locality RP012 (*), an exposure of the limestones of the Lower Oligocene Juana Diaz Formation. Alex Kittle (Delaware Museum of Natural History) for scale

site POR (Figs. 3, 4) on the northwestern end of Bahía Inutil. The locality corresponds to coastal bluffs just west
Fig. 1 Outline locality map of Florida Museum of Natural History Locality RP012 (*). The inset shows the position of the main map within Puerto Rico

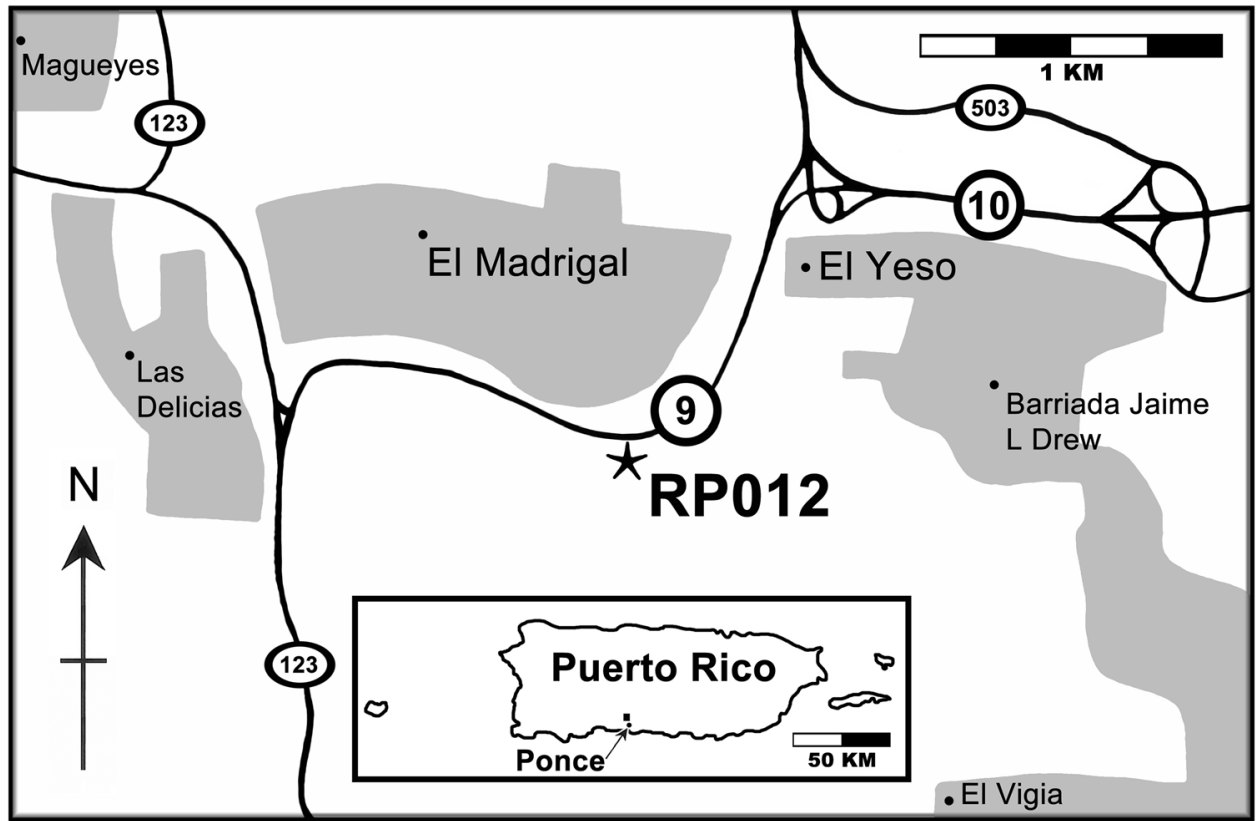




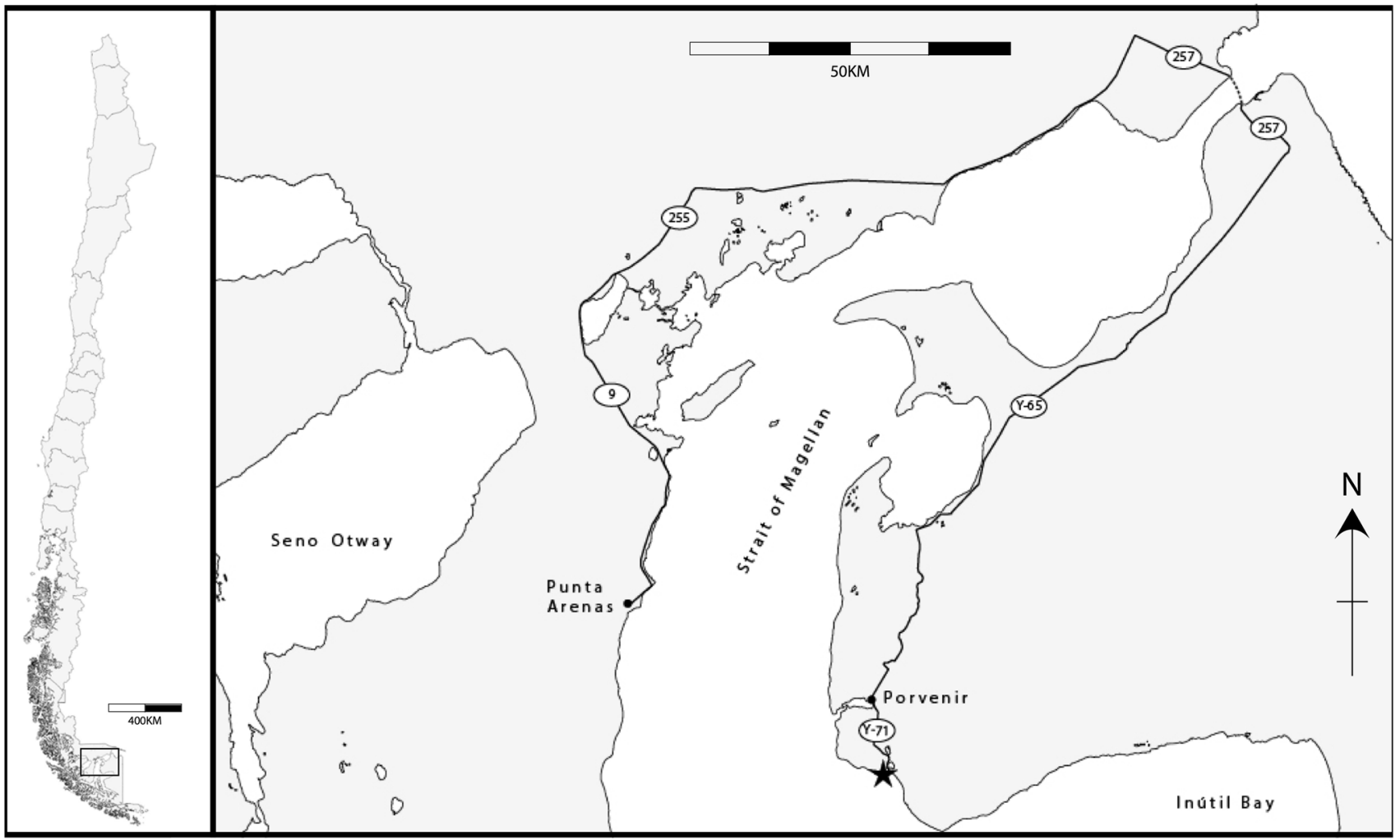

Fig. 3 Outline locality map of locality POR (*), Straits of Magellan, Tierra del Fuego. Inset map (left) shows the position of the main map within Chile
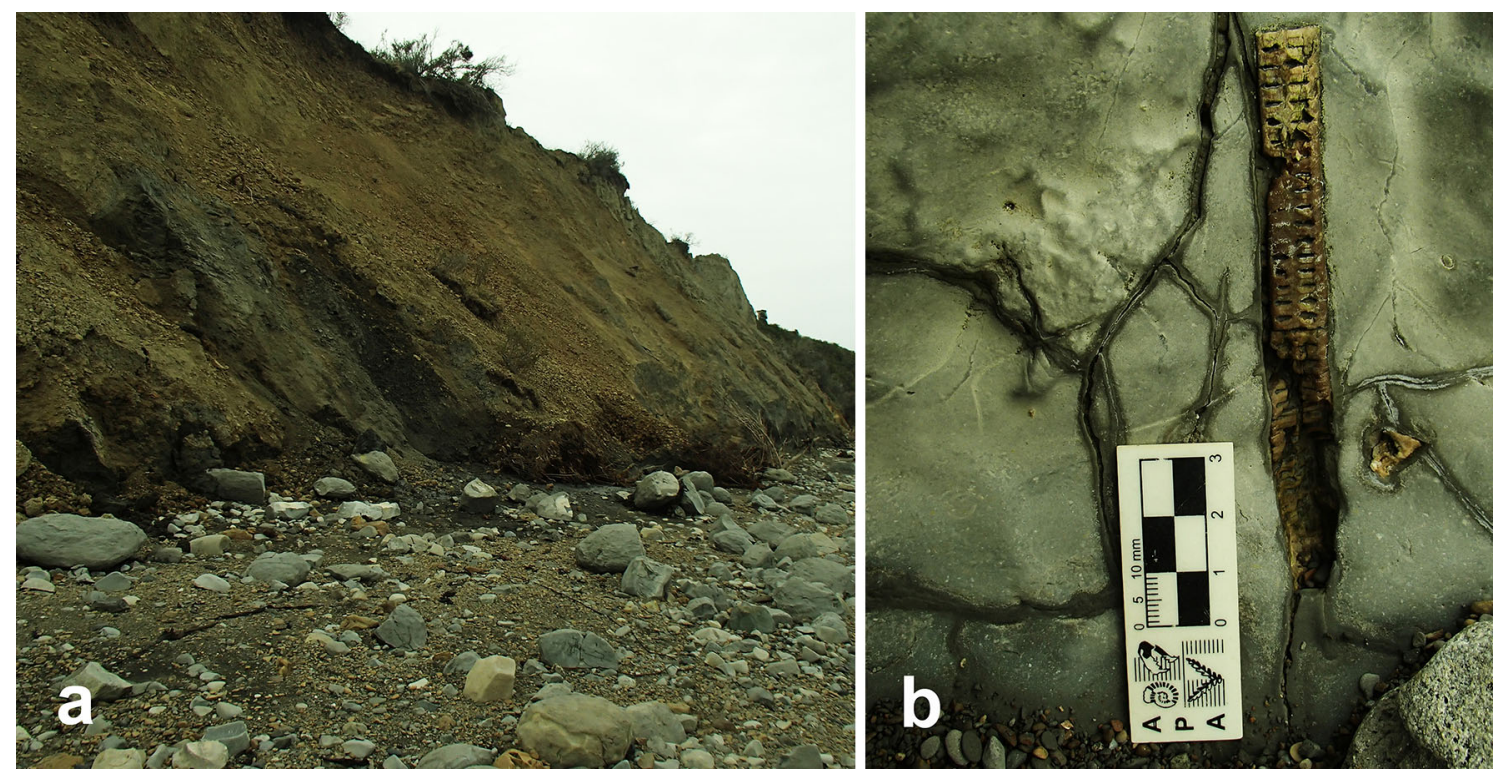

Fig. 4 Locality (POR) for Isselicrinus sp. A, upper Eocene, likely Moritzian Stage, Tierra del Fuego. a Coastal exposure, beds dipping towards right. Boulders on beach less than $1 \mathrm{~m}$ diameter. b In situ Isselicrinus sp. A pluricolumnal, almost $100 \mathrm{~mm}$ long, but incomplete. Scale in $\mathrm{cm}$

of where the road from the town of Porvenir reaches the bay (GPS $53^{\circ} 23^{\prime} 43.19^{\prime \prime} \mathrm{S}, 70^{\circ} 20^{\prime} 38.78^{\prime \prime} \mathrm{W}$, WGS84). The bluffs consist of grey siltstones to fine-grained sandstones and likely belong to the upper Eocene of the Moritzian Stage, deposited in water 1000-2000 m deep (Natland and Gonzalez 1974). The fossil content is low. The sedimentary 
rocks contain mostly moulds of aragonitic molluscs associated with a few calcitic taxa like ostreid and pinnid bivalves. However, originally aragonitic taxa, like the nautiloid Aturia sp., occur recrystallized to calcite in calcareous concretions (Nielsen et al. 2009).

\section{Materials and methods}

Crinoid remains are in an 'as collected' state. Specimens were not whitened for photography. All photography was by a Canon G11 digital camera. Images in Figs. 5 and 6 were manipulated by Photoshop.

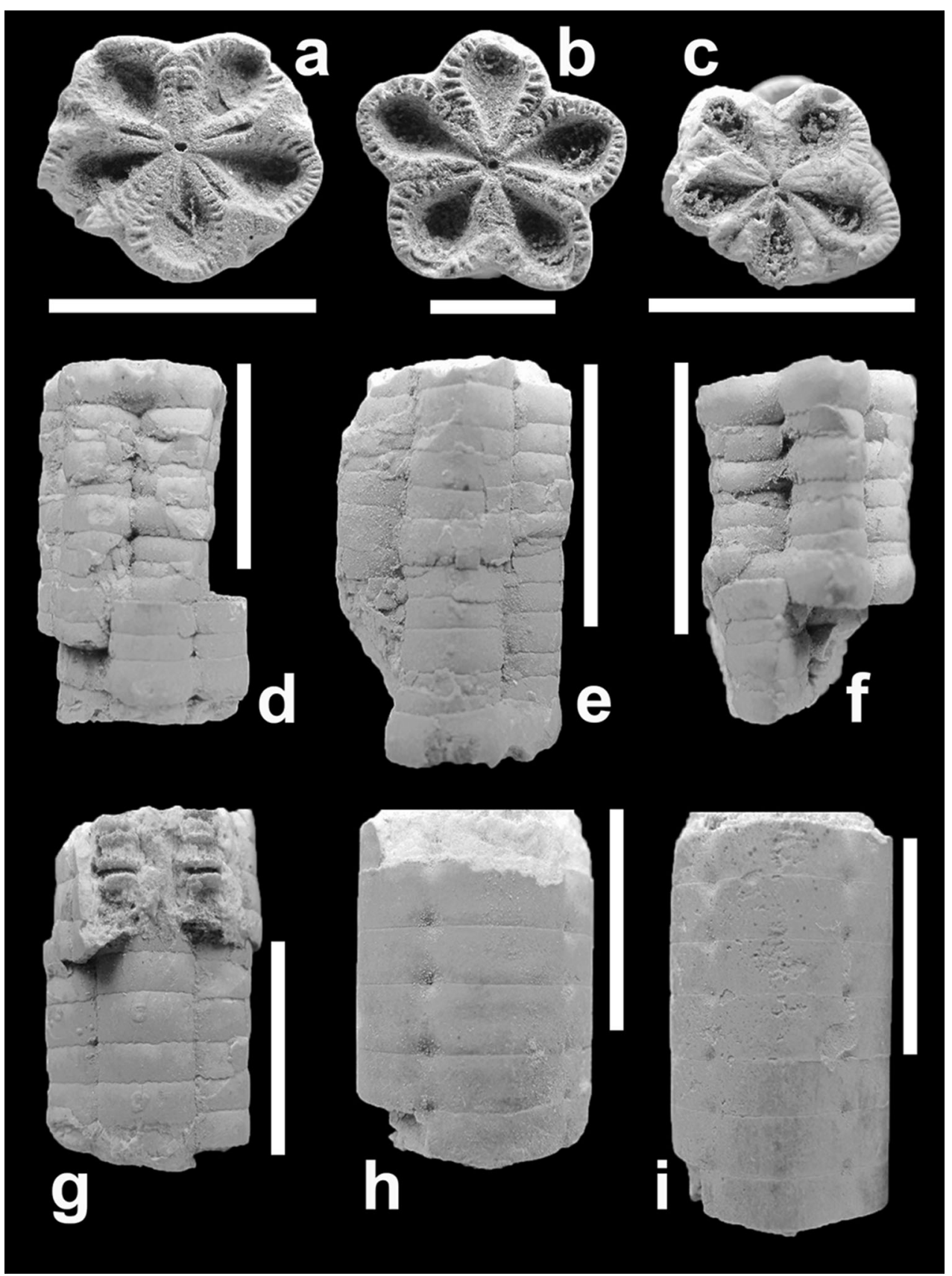

Fig. 5 Isselicrinus sp. A, pluricolumnals, upper Eocene of Tierra del Fuego. a-c Show articular facets; d-i show lateral views of heteromorphic pluricolumnals. a, d RGM.1332404. a Nodal articular facet with three cirrus scars, angled to column long axis, and at 2, 5 and 10 o'clock. d Pluricolumnal (proxistele) with strong grooves (sutures?) between lobes; nodal at top; column displaced near bottom. b, f RGM.1332406. b Articular facet of internodal. f Proxistele. c, g RGM.1332409. c Articular facet of internodal. g Proxistele. e RGM.1332407, proxistele. h RGM.1332408, dististele. i RGM.1332405, dististele. Specimens uncoated. All scale bars represent $10 \mathrm{~mm}$ 


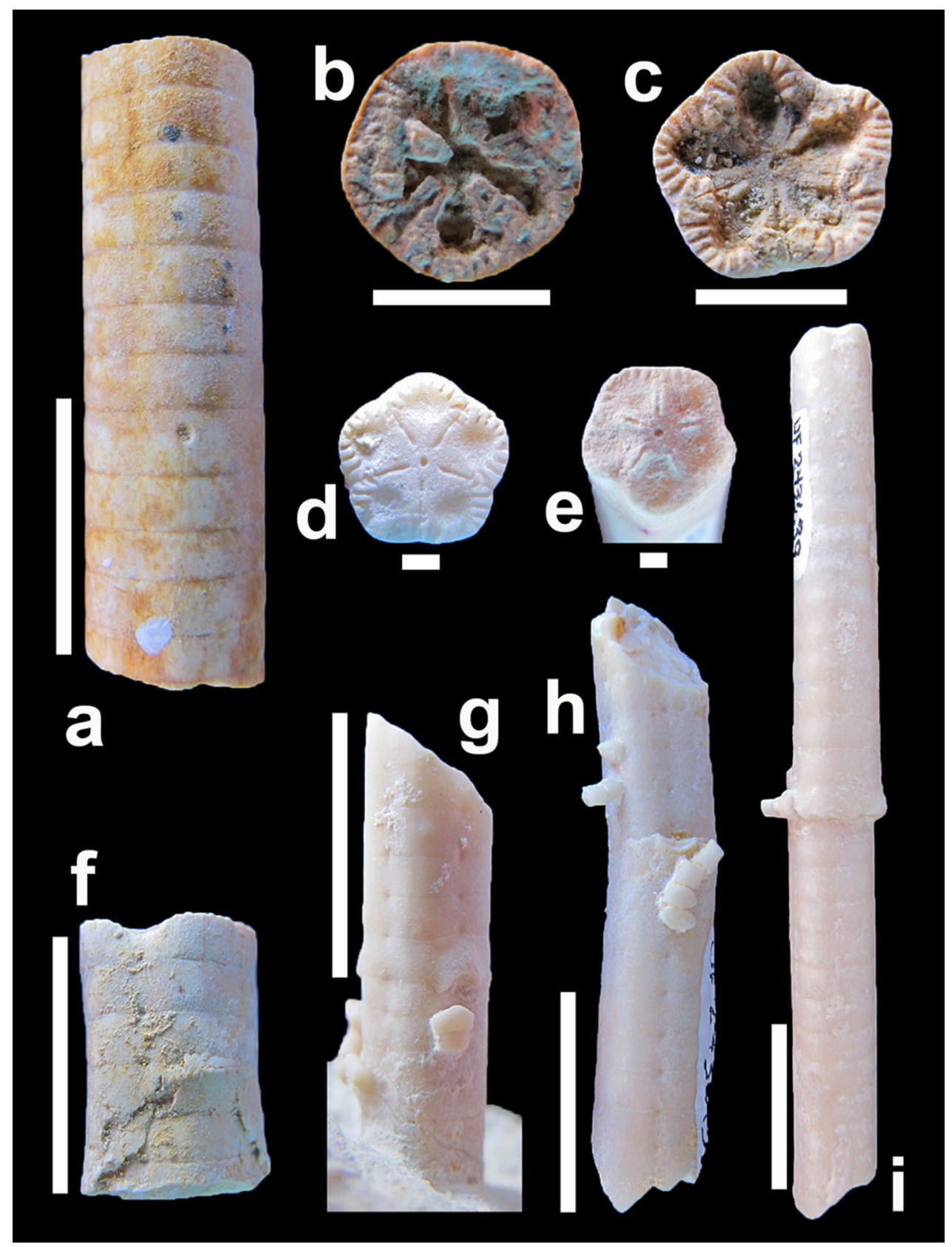

Fig. 6 Isselicrinus sp. B, columnal and pluricolumnals, Florida Museum of Natural History Locality RP012 (*), Lower Oligocene Juana Diaz Formation. b-e Show articular facets; $\mathbf{a}, \mathbf{f}-\mathbf{i}$ show lateral views of heteromorphic pluricolumnals. a, b UF 231456, one specimen of two. a Lateral view. b Articular facet. Scale bar represents $5 \mathrm{~mm}$. c, f UF 231456, second specimen of two. c Articular facet. Scale bar represents $5 \mathrm{~mm}$. f Lateral view. d UF 243689, columnal, articular facet. Scale bar represents $1 \mathrm{~mm}$. e, i UF 243639, cirriferous pluricolumnal. e Articular facet. Scale bar represents $1 \mathrm{~mm}$. i Lateral view. g UF 243648, pluricolumnal. h UF 243693, cirriferous pluricolumnal. Specimens uncoated. Scale bars represent $10 \mathrm{~mm}$ unless stated otherwise

\section{Systematic palaeontology}

Remarks The classification of the articulate crinoids used herein follows Hess and Messing (2011).

Class Crinoidea J.S. Miller, 1821

Subclass Articulata von Zittel, 1879

Order Isocrinida Sieverts-Doreck, 1952
Suborder Isocrinina Sieverts-Doreck, 1952

Family Isselicrinidae Klikushin, 1977

Subfamily Isselicrininae Klikushin, 1977

Genus Isselicrinus Rovereto, 1914

Type species Isselicrinus insculptus Rovereto, 1914, p. 177 (= ?Pentacrinus didactylus d'Orbigny in d'Archiac, 1846), by monotypy, from the Oligocene of Ligurien, 
coastal north-west Italy (Biese and Sieverts-Doreck 1971; Jagt 1999, p. 74; Hess in Hess and Messing 2011, p. 61).

Diagnosis of stem (After Hess in Hess and Messing 2011, p. 63.) "Column cylindrical, pentalobate, or pentagonal to stellate in cross section. Columnal facets in most species similar to Balanocrinus, with uniform marginal crenulae and with adradial ridges or ribbons of minor crenulae or granules. However, some specimens, especially with small or pentalobate columnals, have a more or less gradual transition from marginal to adradial crenulae similar to Isocrinus, although petals are generally wide, drop shaped and almost subtriangular. Cirrus sockets rather small, facing downward from lower edge of nodal. Cirri short and slender".

Remarks The stated similarity of some columnals to Isocrinus is of note. Isocrinus sensu stricto is restricted to the Mesozoic (Hess in Hess and Messing 2011, p. 50), yet columnals of similar morphology have been reported from the Antilles (e.g., Donovan and Veltkamp 2001, Middle Miocene Grand Bay Formation of Carriacou; Donovan et al. 2015, Upper Oligocene Antigua Formation of Antigua). Further comparisons may demonstrate these to be Isselicrinus, albeit distinct from those described herein (see below).

Klikushin (1977) subdivided the genus Isselicrinus into three subgenera, Isselicrinus Isselicrinus Rovereto, I. Praeisselicrinus Klikushin and I. Buchicrinus Klikushin. Praeisselicrinus was subsequently elevated to generic status, but Buchicrinus is not currently distinguished from Isselicrinus (Hess in Hess and Messing, 2011, pp. 61-65).

Range Upper Cretaceous (Maastrichtian) to Neogene (Miocene) (Hess in Hess and Messing, 2011, p. 63).

Isselicrinus sp. A

Figure 5

Material Six figured pluricolumnals, RGM.13324041332409 (Fig. 5); a further 14 specimens, RGM.1332410, are too fragmentary to be illustrated.

Locality and horizon Coastal bluffs at the northwestern corner of Bahía Inutil, upper Eocene, likely Moritzian Stage (Natland and Gonzalez 1974), Tierra del Fuego (Figs. 3, 4).

Description Heteromorphic crinoid pluricolumnals. Columnals vary from pentalobate (Fig. $5 \mathrm{a}-\mathrm{g}$ ) to rounded pentagonal in outline (Fig. 5h, i) and are all moderately large in diameter (c. $10 \mathrm{~mm})$. Lumen is central, small, circular, surrounded by a low, circular perilumen. Areola comprised of five deeply sunken and teardrop-shaped petaloid pits in angles of the articular facet. Each areola petal is completely surrounded by a crenularium of short to peg-like crenulae; shorter, slender crenulae are rarer and situated between those extending for the full width. Each petaloid lobe is separated from each of its neighbours by a shallow groove gently widening toward the circumference except where truncated by a cirrus scar in nodals.

Three cirrus scars at the edge of the best preserved, proximal nodal facet (Fig. 5a). Cirrus scars are small, triangular, angled away from the facet and the latus. Cirrus lumen small, central and flanked by short fulcral ridges which appears serrated in one example. Cirrus facet depressed on either side of fulcrum.

Pluricolumnals vary from strongly pentalobate with convex latera to rounded pentagonal with planar latera. Latera smooth and unsculptured. Pentalobate pluricolumnals have a central suture(?) or groove along the length of each face of the latus; rounded pentagonal pluricolumnals lack such a groove, but there is a line of indentations, each corresponding to a suture between columnals. Pentalobate pluricolumnals have at least three orders of internodals and the nodal in the noditaxes, including at least 15 columnals, but internodals appear to be arrayed irregularly (Fig. 5d). In contrast, rounded pentagonal pluricolumnals have a heteromorphy based on seven internodals, N3231323.

Remarks In this small collection of pluricolumnals, there are two gross morphologies of pluricolumnal, the pentalobate (Fig. 5a-g) and the rounded pentagonal (Fig. 5h, i); all have a similar architecture to their articular facets. These are likely derived from the proximal and distal parts of the column, respectively, of a single species by comparison with other isocrinines (see, for example, Roux 1977; Donovan 1984).

\section{Isselicrinus sp. B}

Figure 6

? 2005 Isselicrinus sp.; Malumián and Olivero; fig. 3.

Material Six specimens, all UF: UF 231456 (two pluricolumnals; Fig. 6a-c, f); 243639 (long pluricolumnal; Fig. 6e, i); 243648 (pluricolumnal; Fig. 6g); 243689 (columnal; Fig. 6d); and 243693 (pluricolumnal; Fig. 6h).

Locality and horizon Northwestern side of Ponce; road cut on the southwestern side of PR-9, about $1.1 \mathrm{~km}$ east of junction with PR-123 (Fig. 1). Thinly bedded limestone; lower Oligocene Juana Diaz Formation.

Description Articular facets depressed centrally (Fig. 6c), although this may be an artefact of corrasion (compare with Malumián and Olivero 2005, fig. 3), or not (Fig. 6b, d, e). Lumen small, central, circular, surrounded by a low, rounded perilumen. Areola petals are teardropshaped to broader and more triangular, either strongly depressed (Fig. 6b, c) or less so (Fig. 6d), becoming nearplanar (Fig. 6e). Crenularium well-developed at circumference, not extending all the way to the perilumen. Crenulae short, unbranched, approximately perpendicular to the circumference of the petals. Petals separated by shallow, radial grooves.

Pluricolumnals typified by long noditaxes (Fig. 6g-i). Figure $6 \mathrm{c}$ shows the proximal articular facet of a nodal 
bearing to cirrus scars angled away at $c .45^{\circ}$ (at 1 and 6 o'clock as illustrated), possibly with the most proximal cirral ossicles still articulated. Cirral canal small, central.

The shortest pluricolumnal (Fig. 6f) is an incomplete noditaxis with unsculptured, slightly convex latera; the second specimen UF 231456, of similar form, is longer, comprised of 12 or more columnals and an incomplete(?) internoditaxis. In the centre of all sides there are circular depressions corresponding to plate sutures, corresponding to the grooves on the articular facets that separate the petals. The patterns of insertions of internodals appear illdefined.

The longest pluricolumnal (Fig. 6i) is slender with a nodal ossicle at about mid-height, bearing an incomplete cirrus and a further cirrus scar. The cirrus scar is small, angled to the long axis of the pluricolumnal and circular in outline. The cirrus canal is small and central, flanked by a fulcral ridge. Cirrus ossicles are small, rounded and tapering away from the pluricolumnal. Other pluricolumnals have cirrus-bearing nodals at the centre (Fig. 6g, h); the latter pluricolumnal (UF 243693) has the longest preserved cirrus, albeit incomplete.

Remarks The specimens in Fig. 6 may appear to have been 'lumped' together. Although not identical to Isselicrinus sp. A, at least some of the specimens have a similar articular facet (compare Fig. 6b, c with Fig. 5a-c). But the smaller articular facets (Fig. 6d, e) of Isselicrinus sp. B are markedly different from the larger facets included in the same species. The small facets are interpreted as having been derived from a different part of the column, possibly more distal. This is supported, in part, by the similarities of all the pluricolumnals included in Isselicrinus sp. B, with nodals only bearing two cirri and external geometry broadly similar.

A notable feature of three of the five pluricolumnals is that they have not broken into noditaxes, but instead have nodals in the middle (Fig. $6 \mathrm{~g}-\mathrm{i}$ ). That is, they are still articulated at the cryptosymplectial articulations at the distal facet of the nodals, considered the preferred site of initial autotomy in the isocrinine stem (see, for example, Donovan 1984; Hess in Hess and Messing 2011, p. 4). It is probable that these are broken fragments of longer pluricolumnals that had disarticulated at the distal cryptosymplectial articulations of nodal ossicles, but which were broken mechanically after they were exhumed by natural processes shortly before they were collected.

\section{Discussion}

The two species assigned to Isselicrinus herein have obvious similarities, but also some marked differences. The Puerto Rican sp. B is typified by slender pluricolumnals, always rounded pentagonal in section (compare with $I S$ selicrinus subbasaltiformis (J. S. Miller, 1821); Rasmussen 1972, pl. 1, figs. 2, 3a), whereas those from the Tierra del Fuego sp. A have more robust columns that vary from pentalobate to pentagonal in section. Petals of areolae are more consistently depressed in the sp. A (compare Fig. 5ac with Fig. 6b-e), although this observation is prejudiced by the small sample sizes. However, in part, it echoes the observations of Rasmussen (1961, pp. 44-45).

The most interesting comparison of these specimens is with Isselicrinus sp. from the late middle Eocene of Tierra del Fuego (Malumián and Olivero 2005, fig. 3). Although only one articular facet is illustrated, in the present samples this figure most closely resembles a specimen from Puerto Rico (Fig. 6c) rather than with any of the specimens from Tierra del Fuego (Fig. 5).

Acknowledgements Two anonymous reviewers made several constructive comments, which we gratefully acknowledge. We thank Sean Roberts (UF) for assistance in drafting Fig. 1. This is University of Florida Contribution to Paleobiology 861.

\section{References}

Archiac, A. D. d' (1846). Description des fossils recueillis par M. Thorent, dans la couche à nummulines des environs de Bayonne. Mémoires de la Société Géologique de France, série 2, 1846, 189-217.

Biese, W., \& Sieverts-Doreck, H. (1971). Fossilium Catalogus. I: Animalia. Pars 80: Crinoidea caenozoica. Reprint [first published 1939]. Den Haag: W. Junk.

Blake, D. B., Donovan, S. K., Mah, C. L., \& Dixon, H. L. (2015). Asteroid (Echinodermata) skeletal elements from the Upper Oligocene of Jamaica and Antigua. Geological Magazine, 152, 1043-1056.

Dixon, H. L., \& Donovan, S. K. (1998). Oligocene echinoids of Jamaica. Tertiary Research, 18, 95-124.

Dixon, H. L., Donovan, S. K., \& Veltkamp, C. J. (1994). Crinoid and ophiuroid ossicles from the Oligocene of Jamaica. Caribbean Journal of Science, 30, 143-145.

Donovan, S. K. (1984). Stem morphology of the Recent crinoid Chladocrinus (Neocrinus) decorus. Palaeontology, 27, 825-841.

Donovan, S. K. (1995). Isocrinid crinoids from the late Cenozoic of Jamaica. Atlantic Geology, 30, 195-203.

Donovan, S. K., Harper, D. A. T., \& Portell, R. W. (2015). In deep water: A crinoid-brachiopod association in the Late Oligocene of Antigua, West Indies. Lethaia, 48, 291-298.

Donovan, S. K., \& Veltkamp, C. J. (2001). The Antillean Tertiary crinoid fauna. Journal of Paleontology, 75, 721-731.

Hess, H. (1999). Recent. In H. Hess, W. I. Ausich, C. E. Brett, \& M. J. Simms (Eds.), Fossil crinoids (pp. 233-236). Cambridge: Cambridge University Press.

Hess, H., \& Messing, C. G. (2011). Treatise on invertebrate paleontology, Part T, Echinodermata 2, revised, Crinoidea (Vol. 3). Lawrence: University of Kansas Paleontological Institute.

Jagt, J. W. M. (1999). Late Cretaceous-Early Palaeogene echinoderms and the $\mathrm{K} / \mathrm{T}$ boundary in the southeast Netherlands and 
northeast Belgium-Part 2: crinoids. Scripta Geologica, 116, $59-255$.

Klikushin, V. G. (1977). Morskiye lilii roda Isselicrinus. Paleontologicheskiǔ Zhurnal, 1977(1), 87-95. [English translation: Sea lilies of the genus Isselicrinus. Paleontological Journal, 1977 (1), 82-89].

Larue, D. K. (1994). Puerto Rico and the Virgin Islands. In S. K. Donovan, \& T. A. Jackson (Eds.), Caribbean geology: An introduction (pp. 151-165). Kingston: U.W.I. Publishers' Association.

Malumián, N., \& Olivero, E. B. (2005). Shallow-water late middle Eocene crinoids from Tierra del Fuego: A new southern record of a retrograde community structure. Scientia Marina, 69(Suppl. 2), 349-353.

Miller, J. S. (1821). A natural history of the Crinoidea or lily-shaped animals, with observations on the genera Asteria, Eurayle, Comatula and Marsupites. Bristol: C. Frost.

Moore, R. C., Jeffords, R. M., \& Miller, T. H. (1968). Morphological features of crinoid columns. University of Kansas Paleontological Contributions, Echinodermata Article, 8, 1-30.

Moore, R. C., with additions by Ubaghs, G., Rasmussen, H. W., Breimer, A., \& Lane, N. G. (1978). Glossary of crinoid morphological terms. In R. C. Moore \& C. Teichert (Eds.), Treatise on invertebrate paleontology. Part T. Echinodermata 2(1) (pp. T229, T231, T233-T242). Boulder and Lawrence: Geological Society of America and University of Kansas Press.

Natland, M. L., \& Gonzalez, E. P. (1974). Geology and paleontology of Magallanes Basin. In M. L. Natland, E. P. Gonzalez, A. Cañon, \& M. Ernst (Eds.), A system of stages for correlation of
Magellanes Basin sediments, vol. 139 (pp. 3-57). Geological Society of America Memoir.

Nielsen, S. N., Bandel, K., \& Kröger, B. (2009). Palaeobiogeographical provenance, taphonomy, and mode of life of Aturia cubaensis (Cephalopoda, Nautiloidea) from Cainozoic deposits of Chile. Geobios, 42, 73-88.

Rasmussen, H. W. (1961). A monograph on the Cretaceous Crinoidea. Det Kongelige Danske Videnskabernes Selskab, Biologiske Skrifter, 12(1), 1-428.

Rasmussen, H. W. (1972). Lower Tertiary Crinoidea, Asteroidea and Ophiuroidea from northern Europe and Greenland. Det Kongelige Danske Videnskabernes Selskab, Biologiske Skrifter, 19(7), 1-83.

Roux, M. (1977). The stalk-joints of Recent Isocrinidae (Crinoidea). Bulletin of the British Museum (Natural History), Zoology Series, 32, 45-64.

Rovereto, G. (1914). Nuovi studi sulla stratigrafia e sulla fauna dell'Oligocene Ligure. Genova: Oliveri.

Sieverts-Doreck, H. (1952). In R. C. Moore, C. G. Lalicker, \& A. G. Fischer, Invertebrate fossils (p. 614). New York: McGraw-Hill.

Ubaghs, G. (1978). Skeletal morphology of fossil crinoids. In R. C. Moore \& C. Teichert (Eds.), Treatise on Invertebrate Paleontology. Part T. Echinodermata 2(1) (pp. T58-T216). Boulder and Lawrence: Geological Society of America and University of Kansas Press.

von Zittel, K. A. (1876-1880). Handbuch der Palaeontologie, Band 1, Palaeozoologie. Abt. 1. München und Leipzig: R. Oldenbourg.

Webster, G. D. (1974). Crinoid pluricolumnal noditaxis patterns. Journal of Paleontology, 48, 1283-1288. 